University of Nebraska - Lincoln

DigitalCommons@University of Nebraska - Lincoln

Faculty Publications: Department of

Entomology

Entomology, Department of

2013

Aquatic Macroinvertebrate Communities and Water Quality at

Buffered and Non-Buffered Wetland Sites on Federal Waterfowl

Production Areas in the Rainwater Basin, Nebraska

John R. Riens

U.S. Fish and Wildlife Service, john_riens@fws.gov

Matt S. Schwarz

U.S. Fish and Wildlife Service

Fatima Mustafa

University of Nebraska-Lincoln

William Wyatt Hoback

Oklahoma State University - Main Campus, whoback@okstate.edu

Follow this and additional works at: https://digitalcommons.unl.edu/entomologyfacpub

Part of the Entomology Commons

Riens, John R.; Schwarz, Matt S.; Mustafa, Fatima; and Hoback, William Wyatt, "Aquatic Macroinvertebrate Communities and Water Quality at Buffered and Non-Buffered Wetland Sites on Federal Waterfowl Production Areas in the Rainwater Basin, Nebraska" (2013). Faculty Publications: Department of Entomology. 347.

https://digitalcommons.unl.edu/entomologyfacpub/347

This Article is brought to you for free and open access by the Entomology, Department of at DigitalCommons@University of Nebraska - Lincoln. It has been accepted for inclusion in Faculty Publications: Department of Entomology by an authorized administrator of DigitalCommons@University of Nebraska - Lincoln. 


\title{
Aquatic Macroinvertebrate Communities and Water Quality at Buffered and Non-Buffered Wetland Sites on Federal Waterfowl Production Areas in the Rainwater Basin, Nebraska
}

\author{
John R. Riens • Matt S. Schwarz • Fatima Mustafa • \\ W. Wyatt Hoback
}

Received: 14 January 2013 / Accepted: 10 July 2013

(C) US Government 2013

\begin{abstract}
Nebraska's Rainwater Basin has an abundance of natural wetlands and is a focal point in the annual migration corridor used by millions of waterfowl and shorebirds. However, these wetlands are in a landscape dominated by agriculture and as a result, siltation and poor water quality are continual problems. We evaluated twelve wetland sites on federally managed Waterfowl Protection Areas from 2007 - 2009 for water quality, sediment quality, and macroinvertebrate diversity. Six of the sites received agricultural runoff directly via culverts and drainage ditches (non-buffered sites) and six sites were protected from agricultural runoff by a vegetated buffer (buffered sites). Mean total number of aquatic macroinvertebrates were significantly greater $(p<0.001)$ for buffered sites $(230 \pm 44$ standard error) than non-buffered sites $(97 \pm 24)$. Water from non-buffered sites had significantly greater turbidity, conductivity, and concentrations of chlorophyll $\alpha$ and atrazine than buffered sites in addition to consistently greater annual averages of total nitrogen and total phosphorus. Furthermore, sediments from non-
\end{abstract}

The information stated in this article has not been published elsewhere.

J. R. Riens $(\bowtie)$

United States Fish and Wildlife Service, 1936 California Ave.,

Klamath Falls, OR 97601, USA

e-mail: john_riens@fws.gov

\section{S. Schwarz}

United States Fish and Wildlife Service, 420 South Garfield Ave., Pierre, SD 57501, USA

\section{F. Mustafa}

University of Nebraska-Lincoln, 103 Entomology, Lincoln, NE 68583, USA

W. W. Hoback

University of Nebraska at Kearney, 2401 11th Avenue, Kearney, NE 68849, USA buffered sites had significantly greater cadmium, potassium, sodium and zinc than buffered sites. Use of vegetative buffers to intercept direct row-crop runoff can improve water quality and aquatic macroinvertebrate diversity and abundance in Rainwater Basin wetlands.

Keywords Macroinvertebrate $\cdot$ Rainwater basin $\cdot$ Vegetative buffers $\cdot$ Environmental contaminants $\cdot$ Water quality

\section{Introduction}

Aquatic macroinvertebrates are well represented in most freshwater bodies throughout the world and play a critical role in the structure and function of most aquatic ecosystems, especially wetlands (Mitsch and Gosselink 2000; Williams 2006). Macroinvertebrates provide essential nutrients (proteins, lipids, and energy) for secondary consumers (e.g. waterfowl, shorebirds, fish, amphibians, and other vertebrate predators) and aid in maintenance of water quality by facilitating organic decomposition and nutrient cycling (Batzer et al. 1999; Davis and Bidwell 2008). Because of their sensitivity to disturbance, aquatic macroinvertebrate communities are also excellent biological indicators for evaluating health of various wetland ecosystems (Adamus 1996; Resh et al. 1996).

The central Nebraska Rainwater Basin (Fig. 1) serves as a midway migratory stopover for millions of waterfowl and shorebirds but is also one of the most endangered wetland ecosystems in North America (Schildman and Hurt 1984; Smith 1998). Five to nine million ducks and several hundred thousand geese stop in the Rainwater Basin annually and as many as 30 species of migrant shorebirds use the region each year, making it one of the most productive bird habitats in the world. However, agricultural development has reduced wetland area in the Rainwater Basin to $10 \%$ of its former 40,500 ha 


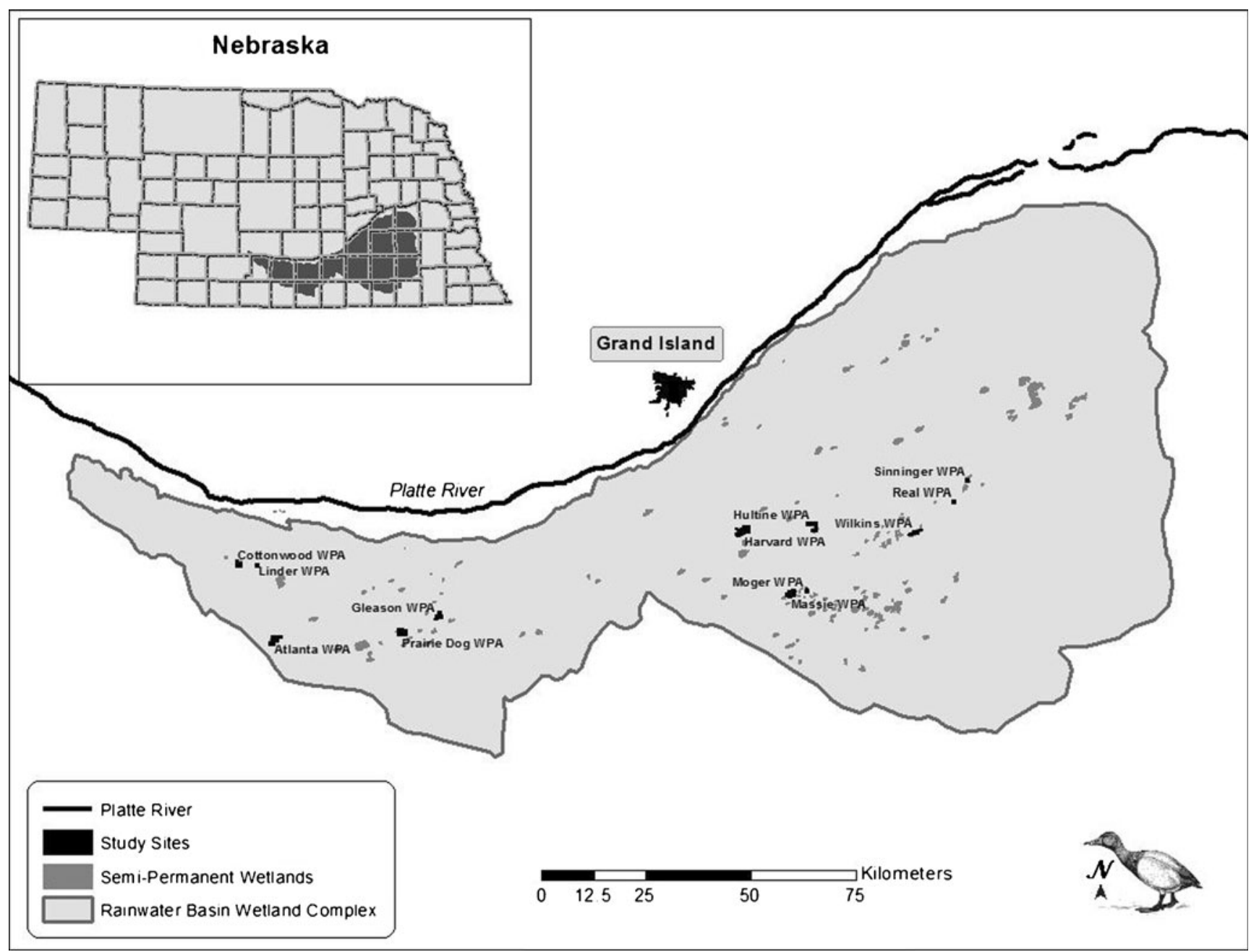

Fig. 1 Site Map. Figure Credit: Rainwater Basin Joint Venture

with remaining wetlands subject to siltation, water quality degradation, and altered hydrology from irrigation runoff (LaGrange 2005).

Wetland degradation and alteration of macroinvertebrate fauna can result from adjacent agricultural land use practices that result in water pollution, sedimentation and altered wetland hydrology (Van Dam et al. 1998; Schulz 2004). Agricultural chemical exposure within wetlands may harm wildlife directly (e.g. exposure to harmful levels of pesticides or metals) or indirectly (e.g. nutrient related changes in vegetation composition and density). Aquatic invertebrates have been used as bioindicators to test the function of constructed wetlands and wastewater treatment areas (Nelson et al. 2000; Spieles and Mitsch 2000) and the success of wetland restoration efforts (Sewell and Higgins 1991; Hemesath 1991; Davis and Bidwell 2008), but few studies have evaluated macroinvertebrates in natural wetlands. Within the Prairie Pothole region of South Dakota, Euliss and Mushet (1999) reported that wetlands adjacent to grassland systems had significantly greater richness and abundance of cladoceran eggs, snail shells, and ostracod shells than wetlands adjacent to croplands, but few other studies have used measurements of physicochemistry and macroinvertebrate assemblage structure to assess the health of natural wetlands.

In Nebraska, the U. S Fish and Wildlife Service (Service) Rainwater Basin Wetland Management District (WMD) manages approximately 61 federally owned Waterfowl Production Areas (WPAs) to protect and conserve wetland habitat for wildlife and public use (Service 2007). Many of these WPAs receive runoff directly from adjacent corn or soybean agricultural fields. Several WPAs also have large concentrated animal feeding operations (CAFOs) within their watersheds (Schwarz et al. 2004). Runoff from row-crop fields or feedlot areas enters some WPAs directly through drainage ditches and culverts (non-buffered sites), whereas others receive nonpoint source agricultural runoff after it has been buffered by vegetation (buffered sites).

Information regarding pollution in Rainwater Basin wetlands is lacking. Gordon et al. (1997) evaluated contaminants in Rainwater Basin wetlands, including WPA sites, and found 
concentrations of mercury, copper, lead, iron, and zinc that exceeded water quality criteria, and concluded that high pesticide and fertilizer use in the area may be the cause. More recently Belden et al. (2012) commonly detected atrazine, acetochlor, metolachlor and trifluralin in Rainwater Basin wetland sediments. Although concentrations were below known acute toxicity thresholds, the authors concluded the potential for chronic effects on resident biota was largely unknown. They also concluded from their sediment data that waterborne atrazine concentrations could exceed those found in sediments and could cause intersex frogs (Hayes et al. 2010). A publication associated with the current study, Papoulias et al. (2012), found that Plains leopard frog (Lithobates blairi) metamorphs exposed to atrazine and glyphosate at four WPA sites in the Rainwater Basin exhibited ovarian dysgenesis, high rates of testicular oocytes, and female-biased sex ratios. Although there were no clear statistical association between pesticide concentrations and frog biomarkers, timing and duration of exposures were unknown.

Within the Rainwater Basin, Gordon et al. (1990) provided some baseline data on aquatic invertebrate taxonomic richness. More recently, Davis and Bidwell (2008) reported no difference in macroinvertebrate assemblage structure among ponds subject to differing riparian vegetation management techniques (prescribed burning, cattle grazing, disking, and mowing). The authors suggested that surrounding land use practices had a greater influence on macroinvertebrate assemblages than local vegetation management techniques. We are not aware of any studies that have simultaneously compared wetland sediment and water quality with aquatic macroinvertebrate assemblages at sites with and without vegetative buffers to intercept runoff from agricultural fields. Thus, the purpose of the present study was to evaluate aquatic macroinvertebrate communities and pollutant concentrations in samples from buffered and non-buffered WPA sites in the Rainwater Basin.

\section{Materials and Methods}

\section{Study Area}

The Rainwater Basin encompasses 17 counties across the south-central region of Nebraska (Fig. 1). Precipitation ranges from $45 \mathrm{~cm} /$ year in the west to $60 \mathrm{~cm} /$ year in the east (Pederson et al. 1989), with winter low temperatures averaging $-17.8 \mathrm{C}$ and summer highs reaching $37.8 \mathrm{C}$ in summer. Topography of the region is flat to gently rolling loess plains with elevations ranging from $455 \mathrm{~m}$ to $758 \mathrm{~m}$ above sea level. Rainwater Basin wetlands are playa wetlands of varying size with substrates consisting of silty loam and clay loam soils (Pederson et al. 1989). These wetlands depend primarily on direct rainfall, surface runoff, and snowmelt
(Bishop et al. 2004). The plant community of the Rainwater Basin includes wet-meadow plants such as sedges (Carex spp.), rushes (Juncus spp.), and spikerush (Eleocharis spp.), moist-soil plants, including smartweeds (Polygonum spp.) and barnyard grass (Echinochloa crusgalli), and emergent plants such as cattail (Typha spp.), bulrushes (Scirpus spp.) and river bulrush (Schoenoplectus fluviatilis) (Bishop et al. 2004).

\section{Field Sites}

This study was conducted on twelve wetland sites, six buffered and six non-buffered, which were chosen among WPAs managed by the Rainwater Basin WMD. Sites were selected based on adjacent land-use, the presence of vegetative buffers, and the likelihood of holding water until August. Buffered sites were Prairie Dog, Real, Massie, Atlanta, Wilkins, and Moger WPAs that had a minimum of $25 \mathrm{~m}$ of vegetative buffer (generally the buffer was much larger than $25 \mathrm{~m}$ ) between surrounding row-crop fields and the water body. Nonbuffered sites were located at Cottonwood, Harvard, Linder, Hultine, Sinninger, and Gleason WPAs at areas that received agricultural runoff directly from adjacent land via drainage culverts or ditches.

\section{Invertebrate Sampling}

Invertebrate sampling was conducted bi-weekly from midApril to early August from 2007 to 2009. For each sampling occasion, four active sweep samples were made with a standard $30.5 \mathrm{~cm} \times 20 \mathrm{~cm}$ D-Frame aquatic net at randomly chosen locations. Each sweep sample consisted of four figure-eight motions of the net through vegetation and open water at depths ranging from $20 \mathrm{~cm}$ to $65 \mathrm{~cm}$. Macroinvertebrates and vegetative material were then gathered from the net and preserved in a $50 \%$ ethyl alcohol solution for later sorting and identification. The D-Frame aquatic net was chosen as the primary sampling method because of its ease of use through dense vegetation (Davis and Bidwell 2008). This technique has also been shown to adequately sample a wide variety of species with few abundant macroinvertebrates absent from resulting collections (Turner and Trexler 1997).

In 2008 and 2009, multi-plate Hester-Dendy samplers consisting of 8 square layers at $0.3 \mathrm{~cm}$ width, two layers at $0.7 \mathrm{~cm}$ width, and two layers at $1.6 \mathrm{~cm}$ width were also used. Four Hester-Dendy passive samplers were placed on the bottom of each wetland and were sampled bi-weekly. Traps were rinsed and returned into the habitat on the same day. Collected material was preserved in a $50 \%$ ethyl alcohol solution for later identification.

In the laboratory, macroinvertebrates were separated from debris with a Leica $200010 \times$ dissecting microscope. Organisms 
were counted and identified to genus when possible. Organisms were identified with keys developed by Douglas (Douglas 2001) and Merritt et al. (2008). Three voucher specimens of each genus were also collected for reference and deposited in the University of Nebraska at Kearney Biology Department collection.

\section{Water Quality}

When macroinvertebrates were sampled, water temperature, dissolved oxygen, conductivity, $\mathrm{pH}$, chlorophyll $\alpha$, turbidity, nitrogen, phosphorus, and chlorides were also sampled at each wetland site. Temperature and dissolved oxygen were measured using a field YSI model 55 Dissolved Oxygen meter. Conductivity and $\mathrm{pH}$ were measured with a Hanna Combo pH \& EC 98,129 m. Measurements for dissolved oxygen, $\mathrm{pH}$, conductivity, and temperature were also measured every two weeks at each site by Service staff using an In-Situ ${ }^{\circledR}$ Inc., Troll 9500 water quality multimeter (Service unpublished data 2009). Chlorophyll $\alpha$ was analyzed with an Aquafluor 8000 (Turner Design). Turbidity, nitrogen, and phosphorus were measured by the University of Nebraska at Kearney using a Hach DR/870 Colorimeter. Water samples were also collected by the Service and tested for total phosphorus, dissolved phosphorus, total nitrogen, and chlorides by Ward Laboratories Inc. Kearney, Nebraska.

\section{Elemental Contaminants}

Elements were measured in water and sediment by the Service (Service unpublished data 2009). All samples for elemental contaminant analysis were collected into pre-cleaned certified (PC Class) high density polyethylene plastic containers obtained from Environmental Sampling Supply (http://www. essvial.com/). Water samples were collected for total recoverable analysis and were preserved at a $\mathrm{pH}$ near 2 with certified clean nitric acid. Invertebrates for elemental analyses were collected with pole nets separately from community surveys. Sediments were collected with a cleaned stainless steel spoon. All samples were submitted to the Service's Analytical Control Facility (Shepherdstown, WV).

In brief, the analysis of duplicate samples, spiked samples, and standard reference materials generally indicated acceptable levels of precision and accuracy. For elemental contaminants analyses, non-water samples were freeze dried, percent moisture was determined, and results were provided as wet weight (ww) and dry weight (dw) concentrations. For all samples, inductively coupled plasma atomic emission spectrometry was used to determine concentrations of aluminum $(\mathrm{Al})$, boron $(\mathrm{B})$, barium $(\mathrm{Ba})$, beryllium $(\mathrm{Be})$, cadmium $(\mathrm{Cd})$, chromium $(\mathrm{Cr})$, copper $(\mathrm{Cu})$, iron $(\mathrm{Fe})$, magnesium $(\mathrm{Mg})$, manganese $(\mathrm{Mn})$, molybdenum (Mo), nickel (Ni), lead $(\mathrm{Pb})$, potassium $(\mathrm{K})$, sodium $(\mathrm{Na})$, strontium $(\mathrm{Sr})$, vanadium
$(\mathrm{V})$, and zinc $(\mathrm{Zn})$. Mercury $(\mathrm{Hg})$ concentrations were determined by cold vapor atomic absorption, and graphite furnace atomic absorption was used to measure arsenic (As), selenium (Se), and small concentrations of $\mathrm{Pb}$ and $\mathrm{Cd}$. Detailed descriptions of lab methods including sample preparation, sample digestion, Quality Assurance/Quality Control (QA/QC) results, and detection limits are available upon request (http:// chemistry.fws.gov/).

\section{Herbicide Analysis}

Water samples for atrazine and glyphosate analysis were collected in pre-cleaned amber glass containers, immediately cooled on ice and refrigerated until analysis. Atrazine and glyphosate concentrations in water were quantified by Enzyme Linked Immuno Sorbent Assay (ELISA) procedure with kits purchased from Abraxis ${ }^{\mathrm{TM}}$ (Warminster, PA, USA) and according to manufacturer's protocols. The assay ranges were 0.05 to 5 micrograms per liter $(\mu \mathrm{g} / \mathrm{L})$ for atrazine and 0.15 to $\mu \mathrm{g} / \mathrm{L}$ for glyphosate. Samples that exceeded the upper range were re-run following a 10 -fold serial dilution (Service unpublished data 2009).

\section{Statistical Analysis}

Data collected for water quality and element concentrations in sediment were analyzed individually under a repeated measures analysis (PROC GLIMMIX, SAS Institute 2012) to test for significant $(p<0.05)$ differences between buffered and non-buffered sites. Water quality parameters included temperature, $\mathrm{pH}$, dissolved oxygen (DO), conductivity, turbidity, total nitrogen, total phosphorus, orthophosphorus, total phosphorus, atrazine, glyphosate, and chlorophyll $\alpha$. Individual parameters were analyzed using three years of data collection (U.S. Fish and Wildlife Service 2007, 2008, and 2009) from both buffered and non-buffered conditions. Dry weight concentrations of elemental contaminants including aluminum, arsenic, boron, barium, beryllium, cadmium, chromium, copper, mercury, magnesium, manganese, molybdenum, nickel, selenium, strontium, vanadium and zinc from buffered and non-buffered conditions were compared across 2 years $(2008,2009)$.

Sweep sample and Hester-Dendy plate sample data from each site were pooled by sample date and compared independently. The presence of total invertebrates and number of genera in sampled sites were analyzed separately among three years $(2007,2008$, and 2009) and two conditions (buffered, non-buffered). The comparison of individual invertebrate orders (Diptera, Coleoptera, Hemiptera, Odonata (Anisoptera and Zygoptera), Ephemeroptera and gastropoda) among buffered and non-buffered sites among 3 years was also conducted with repeated measures analysis under split plots. 


\section{Results}

\section{Biotic Measures}

Between April 2007 and July 2009, we collected and identified a total of 37,985 macroinvertebrates representing 69 genera (Table 1). Sweep sampling collected significantly more genera from buffered locations $(p<0.001)$. Plate sampling with multi-plate Hester-Dendy samplers was significantly less productive than sweep sampling $(p<0.001)$ but results were similar proportionally when comparing mean numbers of specimens and genera between buffered and nonbuffered sites.

The repeated measure ANOVA for all the invertebrate collection over 3 years for 12 different sites with the categories of buffered and non-buffered showed a significant effect of site conditions and years on invertebrate presence ( $p=0.0117$ and $p=0.0288$ respectively). Invertebrates were found in significantly higher numbers in buffered sites compared to non-buffered sites $(p=0.0117)$. The highest numbers of invertebrates were found in 2009 in buffered sites while the lowest numbers of invertebrates were found in non-buffered sites during 2007 (Table 2).

Among the seven most abundantly collected macroinvertebrate groups, genera diversity was higher in buffered wetlands for all groups except Hemiptera (Table 3). Differences were greatest for dragonfly larvae, mayfly larvae, and lunged snails. Among the groups analyzed, the abundance of all taxa except Hemiptera was significantly higher in buffered sites for at least one of the three years (Table 4). Significantly more Anisoptera and Diptera were collected from buffered sites for all years (Table 4).

\section{Elements}

Mean concentrations of the 21 elements measured in sediments were generally higher on non-buffered sites than buffered sites with non-buffered sites having significantly greater concentrations of cadmium, potassium, sodium and zinc (Table 5). Arsenic, cadmium, lead, and zinc exceeded sediment quality benchmarks for the protection of aquatic life; however, none of the elements measured in sediment exceeded consensus based probable effect concentrations, above which adverse effects are expected to occur more often than not (MacDonald et al. 2000) (Table 5).

\section{Water Quality}

Water from non-buffered sites had significantly greater $(p<0.05)$ turbidity, conductivity, and concentrations of chlorophyll $\alpha$ and atrazine than buffered sites (Table 6). Annual mean concentrations of conductivity, chlorophyll $\alpha$, total phosphorus, orthophosphorus, total nitrogen, turbidity, and atrazine were also consistently greater at non-buffered sites than buffered sites for each year sampled (Table 6).

\section{Discussion}

The number of macroinvertebrates, and the number of genera were significantly greater in wetlands with buffers (Tables 1 and 2) implying that these wetlands are more productive than non-buffered wetlands. Orders containing aquatic larvae that utilize dissolved oxygen including Odonata, Ephemeroptera, prosobranch Gastropoda, and Coleoptera are widely recognized for their sensitivity to pollution inputs and may be sensitive to both short and long-term changes in water quality (Batzer et al. 1999; Mackie 2004). In contrast the mean numbers of Hemiptera were not significantly different between buffered and non-buffered wetlands. A lack of significance for Hemiptera may be attributed to their use of atmospheric oxygen at all life stages which may contribute to survival in water of varying quality (Williams 1996; Voshell 2005).

Other studies of wetlands have found similar results with higher percentages of Hemiptera and Diptera in disturbed and non-buffered sites (Davis and Bidwell 2008). Among the Diptera, some families and genera, such as Chironomidae and Culicidae have adaptations to also use atmospheric oxygen and are less affected by water quality (Williams 1996; Voshell 2005). In the present study, samples from non-buffered wetlands rarely contained orders other than Diptera, Hemiptera, Hirudinea (leaches) and the pulmonate snail, Branchiobdellida sp. However, the Diptera contained significantly more genera and specimens in buffered wetlands than in non-buffered wetlands, mainly as a result of the presence of Ceratopogonidae and Chaoboridae, two groups that utilize dissolved oxygen, in buffered wetlands (Table 1).

The increased nutrients, salts and herbicides detected in water and/or sediments of non-buffered sites likely contribute to the differences we found in aquatic invertebrate assemblages between buffered and non-buffered sites. Others have reported similar associations between increased pollutant concentrations and changes in diversity and abundance of macroinvertebrates (Levy 1998; Euliss and Mushet 1999; Steinman et al. 2003). Annual average concentrations of total nitrogen were consistently higher on non-buffered sites than buffered sites and lower invertebrate taxa richness has been previously observed in wetlands with higher nitrogen levels (Hentges and Stewart 2010). Although most of the contaminants from non-buffered sites had concentrations that were below water quality standards or literature established toxicity thresholds, effects to wetland biota from chronic exposure to a mixture of herbicides, salts and nutrients are not well understood. Furthermore, water quality averages may not be as important as acute effects from exposure to peak concentrations 
Table 1 Number of individuals by sampling method and condition for all invertebrate taxa collected from Rainwater Basin across all years

\begin{tabular}{|c|c|c|c|c|c|c|c|c|}
\hline Order & Family & Genus & BSS & NBSS & BPS & NBPS & $\mathrm{BS}$ & NBS \\
\hline Amphipoda & Hyalellidae & Hayalella & 160 & 299 & 6 & 19 & 5 & 1 \\
\hline \multirow[t]{2}{*}{ Branchiopoda } & Thamnocephalidae & Branchinella & 176 & 230 & 0 & 0 & 1 & 2 \\
\hline & Artemiidae & Artemia & 9 & 74 & 0 & 0 & 1 & 2 \\
\hline \multirow[t]{15}{*}{ Coleoptera } & Dystiscidae & Celina & 348 & 100 & 5 & 0 & 6 & 6 \\
\hline & & Derovatellus & 6 & 3 & 0 & 0 & 3 & 0 \\
\hline & & Dytiscus & 7 & 13 & 1 & 0 & 2 & 1 \\
\hline & & Oreodytes & 59 & 10 & 0 & 0 & 6 & 2 \\
\hline & & Rhantus & 57 & 19 & 0 & 0 & 4 & 4 \\
\hline & Elmidae & Narpus & 18 & 37 & 2 & 0 & 3 & 4 \\
\hline & Gyrinidae & Dineutus & 111 & 36 & 2 & 0 & 6 & 5 \\
\hline & & Gyretes & 18 & 1 & 0 & 0 & 3 & 0 \\
\hline & & Gyrinus & 142 & 47 & 1 & 0 & 6 & 5 \\
\hline & Halipidae & Peltodytes & 45 & 17 & 0 & 0 & 4 & 1 \\
\hline & Helophoridae & Helophorus & 31 & 12 & 0 & 0 & 5 & 2 \\
\hline & Hydrophilidae & Berosus & 1 & 0 & 0 & 0 & 1 & 0 \\
\hline & & Hydrobius & 7 & 5 & 0 & 0 & 2 & 2 \\
\hline & & Tropisternus & 13 & 2 & 0 & 0 & 1 & 1 \\
\hline & Psephenidae & Psephenus & 24 & 7 & 0 & 0 & 2 & 2 \\
\hline \multirow[t]{17}{*}{ Diptera } & Ceratopogonidae & Forcipomyia & 22 & 0 & 0 & 0 & 3 & 0 \\
\hline & & Leptoconops & 5 & 0 & 0 & 0 & 1 & 0 \\
\hline & & Probezzia & 296 & 91 & 0 & 0 & 3 & 2 \\
\hline & & Sphaeromias & 19 & 0 & 0 & 0 & 1 & 0 \\
\hline & Chaoboridae & Chaoborus & 290 & 47 & 0 & 0 & 4 & 2 \\
\hline & Chironomidae & Ceratopogon & 180 & 43 & 1 & 0 & 4 & 2 \\
\hline & & Chironomus & 874 & 831 & 16 & 4 & 6 & 6 \\
\hline & & Cricotopus & 2,611 & 1,920 & 20 & 12 & 6 & 6 \\
\hline & & Odontomesa & 21 & 0 & 0 & 0 & 2 & 0 \\
\hline & & Stictochironomus & 30 & 5 & 0 & 0 & 3 & 0 \\
\hline & Culicidae & Aedes & 340 & 195 & 0 & 0 & 6 & 6 \\
\hline & Dixidae & Meringodixa & 1 & 0 & 0 & 0 & 1 & 0 \\
\hline & Ptychopteridae & Ptychoptera & 3 & 0 & 0 & 0 & 1 & 0 \\
\hline & Stratiomyidae & Odontomyia & 18 & 11 & 0 & 0 & 3 & 1 \\
\hline & & Oxycera & 2 & 0 & 0 & 0 & 1 & 0 \\
\hline & & Myxosargus & 1 & 0 & 1 & 0 & 1 & 0 \\
\hline & Tipulidae & Megistocera & 6 & 0 & 0 & 0 & 1 & 0 \\
\hline \multirow[t]{5}{*}{ Ephemeroptera } & Ephemerellidae & Attenella & 59 & 23 & 0 & 0 & 5 & 1 \\
\hline & & Serratella & 492 & 135 & 7 & 1 & 5 & 2 \\
\hline & Leptohyphidae & Leptohyphes & 705 & 111 & 13 & 0 & 6 & 3 \\
\hline & Potamanthidae & Anthopotamus & 53 & 0 & 0 & 0 & 2 & 0 \\
\hline & Siphlonuridae & Parameletus & 4 & 0 & 0 & 0 & 2 & 0 \\
\hline \multirow[t]{3}{*}{ Gastropoda } & Bithyniidae & Bithynia & 1,321 & 251 & 35 & 33 & 6 & 2 \\
\hline & Physidae & Physella & 2,603 & 1,182 & 108 & 84 & 6 & 6 \\
\hline & Planorbidae & Helisoma & 2,011 & 881 & 87 & 72 & 6 & 6 \\
\hline Haplotaxida & Haplotaxidae & & 4,798 & 2,469 & 53 & 22 & 6 & 6 \\
\hline Haplotaxida & Naididae & & 28 & 0 & 0 & 0 & 1 & 0 \\
\hline \multirow[t]{4}{*}{ Hemiptera } & Belostomatidae & Abedus & 28 & 1 & 0 & 0 & 4 & 0 \\
\hline & Corixidae & Neocorixa & 2,153 & 1,036 & 4 & 0 & 6 & 6 \\
\hline & Gerridae & Gerris & 1 & 3 & 0 & 0 & 1 & 1 \\
\hline & Nepidae & Ranatra & 1 & 0 & 0 & 0 & 1 & 0 \\
\hline
\end{tabular}


Table 1 (continued)

\begin{tabular}{|c|c|c|c|c|c|c|c|c|}
\hline Order & Family & Genus & BSS & NBSS & BPS & NBPS & $\mathrm{BS}$ & NBS \\
\hline & Notonectidae & Notonecta & 1,331 & 997 & 1 & 0 & 6 & 6 \\
\hline Hirudinea & Hirudinidae & & 327 & 338 & 35 & 105 & 6 & 6 \\
\hline Hydrachnidia & Arrenuridae & Arrenurus & 83 & 190 & 0 & 2 & 5 & 4 \\
\hline Notostraca & Triopsidae & Triops & 9 & 6 & 0 & 0 & 1 & 1 \\
\hline \multirow[t]{13}{*}{ Odonata } & Aeshnidae & Boyeria & 18 & 0 & 0 & 0 & 3 & 0 \\
\hline & & Nasiaeschna & 52 & 1 & 0 & 0 & 6 & 1 \\
\hline & Coenagrionidae & Amphiagrion & 328 & 84 & 6 & 0 & 6 & 4 \\
\hline & & Argia & 15 & 0 & 3 & 0 & 2 & 0 \\
\hline & & Chromagrion & 320 & 36 & 12 & 1 & 3 & 2 \\
\hline & & Nehalennia & 218 & 67 & 0 & 0 & 3 & 1 \\
\hline & Lestidae & Archilestes & 1 & 1 & 0 & 0 & 1 & 0 \\
\hline & & Lestes & 704 & 198 & 10 & 2 & 6 & 5 \\
\hline & Libellulidae & Erythemis & 17 & 2 & 0 & 0 & 4 & 1 \\
\hline & & Ladona & 25 & 0 & 0 & 0 & 4 & 0 \\
\hline & & Libellula & 18 & 0 & 0 & 0 & 4 & 0 \\
\hline & & Nannothemis & 9 & 2 & 11 & 0 & 3 & 0 \\
\hline & & Plathemis & 81 & 8 & 9 & 2 & 6 & 3 \\
\hline Poduromorpha & Poduridae & Podura & 2 & 6 & 0 & 0 & 1 & 1 \\
\hline Spinicaudata & Cyzicidae & Caenestheriella & 135 & 55 & 0 & 0 & 4 & 2 \\
\hline Veneroida & Sphaeriidae & Pisidium & 953 & 153 & 28 & 4 & 4 & 3 \\
\hline Total & 42 & 69 & 24,854 & 12,291 & 477 & 363 & & \\
\hline
\end{tabular}

$B S S$ buffered sweep sampling, $N B A S$ non-buffered sweep sampling, $B P S$ buffered plate sampling, $N B P S$ non-buffered plate sampling, $B S$ buffered sites found, and NBS non-buffered sites found

Table 2 Mean number of invertebrates $( \pm$ SE) present in collected samples from Rainwater Basin wetlands which had vegetative buffers $(N=6)$ or were non-buffered $(N=6)$

\begin{tabular}{llr}
\hline $\begin{array}{l}\text { Site conditions } \rightarrow \\
\text { Years } \downarrow\end{array}$ & $\begin{array}{l}\text { Buffered } \\
\text { Mean } \pm \text { SE }\end{array}$ & $\begin{array}{l}\text { Non-Buffered } \\
\text { Mean } \pm \text { SE }\end{array}$ \\
\hline 2007 & $128.2 \pm 34.05^{* *}$ & $80.9 \pm 32.69^{* *}$ \\
2008 & $225.0 \pm 29.59^{* *}$ & $103.8 \pm 26.08^{* *}$ \\
2009 & $228.7 \pm 34.80^{* *}$ & $101.9 \pm 37.74^{* *}$ \\
\hline
\end{tabular}

of elements like nitrogen and phosphorus or lows for dissolved oxygen (Williams 1996; Spieles and Mitsch 2000; Douglas 2001; Mackie 2004; Davis and Bidwell 2008).

Contaminants that exceeded water quality criteria (e.g., atrazine, chromium and zinc) or sediment quality guidelines (e.g. arsenic, cadmium, lead and zinc) may also be directly toxic to invertebrates and responsible for the altered aquatic invertebrate assemblages found on non-buffered sites. In work related to the current study, elements in aquatic invertebrates

Table 3 Mean $( \pm$ S.E.) number of genera from the most common macroinvertebrate orders from buffered and non-buffered wetlands of the Rainwater basin, 2007-2009

\begin{tabular}{llrllllll}
\hline Condition & Year & \multicolumn{1}{c}{ Diptera } & Coleoptera & Hemiptera & Anisoptera & Zygoptera & Ephemeroptera & Gastropoda \\
\hline Buffered & 2007 & $15.3 \pm 5.78$ & $4.2 \pm 0.66$ & $2.0 \pm 0.32$ & $2.4 \pm 1.25$ & $2.4 \pm 0.245$ & $1.4 \pm 0.68$ & $2.6 \pm 0.24$ \\
Buffered & 2008 & $6.2 \pm 0.61$ & $8.2 \pm 0.79$ & $2.7 \pm 0.33$ & $3.3 \pm 0.61$ & $2.7 \pm 0.33$ & $2.3 \pm 0.49$ & $2.7 \pm 0.21$ \\
Buffered & 2009 & $5.4 \pm 1.08$ & $6.2 \pm 1.63$ & $2.4 \pm 0.40$ & $4.2 \pm 1.16$ & $2.8 \pm 0.80$ & $2.6 \pm 0.40$ & $2.8 \pm 0.20$ \\
Non Buffered & 2007 & $2.8 \pm 0.25$ & $2.8 \pm 0.48$ & $2.3 \pm 0.25$ & $0.0 \pm 0.00$ & $1.0 \pm 0.41$ & $0.3 \pm 0.25$ & $2.0 \pm 0.71$ \\
Non Buffered & 2008 & $3.8 \pm 0.54$ & $4.5 \pm 0.67$ & $2.2 \pm 0.17$ & $0.7 \pm 0.33$ & $1.3 \pm 0.49$ & $0.5 \pm 0.22$ & $2.2 \pm 0.31$ \\
Non Buffered & 2009 & $3.3 \pm 0.75$ & $4.3 \pm 0.95$ & $2.0 \pm 0.00$ & $0.3 \pm 0.24$ & $2.0 \pm 0.82$ & $1.3 \pm 0.48$ & $1.0 \pm 0.58$ \\
Buffered & Overall & $5.6 \pm 0.69$ & $6.4 \pm 0.57$ & $2.4 \pm 0.18$ & $3.3 \pm 0.76$ & $2.6 \pm 0.34$ & $2.1 \pm 0.37$ & $2.7 \pm 0.18$ \\
Non Buffered & Overall & $3.47 \pm 0.38$ & $3.9 \pm .33$ & $2.2 \pm 0.17$ & $0.3 \pm 0.17$ & $1.3 \pm 0.43$ & $0.5 \pm 0.25$ & $1.89 \pm 0.39$ \\
\hline
\end{tabular}


Table 4 Comparison of least squares means $( \pm \mathrm{SE})$ of invertebrate by year and site condition

**Indicates significance

\begin{tabular}{lcll}
\hline $\begin{array}{l}\text { Years } \rightarrow \\
\text { Orders } \downarrow\end{array}$ & $\begin{array}{l}2007 \\
\text { Buffered vs. Non-buffered }\end{array}$ & $\begin{array}{l}2008 \\
\text { Buffered vs. Non-buffered }\end{array}$ & $\begin{array}{l}2009 \\
\text { Buffered vs. Non-buffered }\end{array}$ \\
\hline S.O. Anisoptera & $2.276 \pm 0.5136^{* *}$ & $2.1268 \pm 0.4681^{* *}$ & $2.8699 \pm 0.5333^{* *}$ \\
Coleoptera & $1.3027 \pm 0.7735$ & $2.4916 \pm 0.6844^{* *}$ & $0.7266 \pm 0.8143$ \\
Diptera & $2.5484 \pm 0.6153^{* *}$ & $1.9190 \pm 0.5892^{* *}$ & $1.4385 \pm 0.6256^{* *}$ \\
Ephemeroptera & $0.6359 \pm 0.4051$ & $1.1457 \pm 0.3872^{* *}$ & $0.6582 \pm 0.4122$ \\
Hemiptera & $0.02054 \pm 0.2432$ & $0.2149 \pm 0.2156$ & $0.3596 \pm 0.2559$ \\
S.O. Zygoptera & $1.5155 \pm 0.4205^{* *}$ & $0.9480 \pm 0.4029^{* *}$ & $0.5798 \pm 0.4275$ \\
Gastropoda & $0.0648 \pm 29.8049$ & $0.2467 \pm 23.0590$ & $86.292 \pm 34.7^{* *}$ \\
\hline
\end{tabular}

Table 5 Concentrations of metals and metalloids in sediment from buffered and non-buffered sites on Waterfowl Production Areas, Nebraska Rainwater Basin, 2008 and 2009

\begin{tabular}{|c|c|c|c|c|c|c|c|}
\hline \multirow[b]{3}{*}{ Trace Element } & \multicolumn{3}{|c|}{ Buffered Sites } & \multicolumn{3}{|c|}{ Non-buffered Sites } & \multirow{3}{*}{$\begin{array}{l}\text { Published Background or } \\
\text { Threshold Concentrations ( } \mathrm{mg} / \mathrm{kg})\end{array}$} \\
\hline & \multirow[b]{2}{*}{$\mathrm{N}_{\mathrm{D}} / \mathrm{N}_{\mathrm{A}}$} & \multicolumn{2}{|c|}{ Dry Weight Concentration (mg/kg) } & \multirow[b]{2}{*}{$\mathrm{N}_{\mathrm{D}} / \mathrm{N}_{\mathrm{A}}$} & \multicolumn{2}{|c|}{ Dry Weight Concentration (mg/kg) } & \\
\hline & & Mean \pm S.E. & Range & & Mean \pm S.E. & Range & \\
\hline Aluminum & $31 / 31$ & $17424 \pm 1866$ & $7050-41000$ & $45 / 45$ & $19746 \pm 1166$ & $9170-41700$ & $74000^{\mathrm{a}}, 25519^{\mathrm{d}}$ \\
\hline Arsenic & $31 / 31$ & $2.68 \pm 0.11$ & $1.51-4.1$ & $45 / 45$ & $3.67 \pm 0.16$ & $1.04-6.09$ & $1.1^{\mathrm{b}}, 5.9^{\mathrm{c}}, 9.8^{\mathrm{d}}$ \\
\hline Barium & $31 / 31$ & $203 \pm 8$ & $124-292$ & $45 / 45$ & $214 \pm 7$ & $90.6-326$ & $670^{\mathrm{a}}$ \\
\hline Beryllium & $31 / 31$ & $1.07 \pm 0.06$ & $0.66-1.8$ & $45 / 45$ & $1.18 \pm 0.04$ & $0.58-1.62$ & $1^{\mathrm{a}}$ \\
\hline Boron* & $29 / 31$ & $5 \pm 1$ & $1.36-20$ & $45 / 45$ & $6 \pm 1$ & $1.04-30$ & $30^{\mathrm{e}}$ \\
\hline Cadmium* & $27 / 31$ & $0.40 \pm 0.05$ & $0.1-\mathbf{1 . 5}$ & $45 / 45$ & $0.54 \pm 0.02$ & $0.1-0.909$ & $0.3^{\mathrm{b}}, 0.6^{\mathrm{c}}, 1^{\mathrm{d}}, 5^{\mathrm{e}}$ \\
\hline Chromium & $31 / 31$ & $16 \pm 1$ & $7.05-33$ & $45 / 45$ & $17 \pm 1$ & $7.72-36$ & $13^{\mathrm{b}}, 43^{\mathrm{d}}$ \\
\hline Copper & $31 / 31$ & $15 \pm 1$ & $8.42-24$ & $45 / 45$ & $17 \pm 1$ & $6.76-29$ & $25^{\mathrm{b}}, 36^{\mathrm{c}}, 32^{\mathrm{d}}$ \\
\hline Iron & $31 / 31$ & $13265 \pm 768$ & $7130-23100$ & $45 / 45$ & $16284 \pm 492$ & $8500-22000$ & $26000^{\mathrm{a}}$ \\
\hline Lead & $31 / 31$ & $16 \pm 1$ & $7.53-22$ & $45 / 45$ & $20 \pm 1$ & $7.47-\mathbf{3 8 . 5}$ & $17^{\mathrm{b}}, 35^{\mathrm{c}}, 36^{\mathrm{d}}$ \\
\hline Magnesium & $31 / 31$ & $3264 \pm 203$ & $1720-6340$ & $45 / 45$ & $3986 \pm 127$ & $2150-5960$ & $400^{\mathrm{b}}$ \\
\hline Manganese & $31 / 31$ & $203 \pm 10$ & $109-298$ & $45 / 45$ & $252 \pm 12$ & $94.2-578$ & $480^{\mathrm{a}}$ \\
\hline Mercury & $20 / 31$ & $0.044 \pm 0.007$ & $0.009-0.200$ & $31 / 45$ & $0.040 \pm 0.002$ & $0.008-0.100$ & $0.18^{\mathrm{d}} 0.49^{\mathrm{e}}$ \\
\hline Molybednum & $23 / 31$ & $0.78 \pm 0.19$ & $0.085-2.5$ & $33 / 45$ & $0.86 \pm 0.15$ & $0.069-2.5$ & $3^{\mathrm{f}}$ \\
\hline Nickel & $31 / 31$ & $10.84 \pm 0.36$ & $7.59-17$ & $45 / 45$ & $13 \pm 0$ & $6.18-18$ & $10^{\mathrm{b}}, 23^{\mathrm{d}}$ \\
\hline Potassium* & $23 / 23$ & $3517 \pm 185$ & $2170-5890$ & $33 / 33$ & $4850 \pm 197$ & $2790-7240$ & None \\
\hline Selenium & $24 / 31$ & $0.57 \pm 0.05$ & $0.25-1.19$ & $37 / 45$ & $0.86 \pm 0.08$ & $0.25-2.32$ & $0.29^{\mathrm{b}}, 4^{\mathrm{g}}$ \\
\hline Sodium* & $2 / 23$ & $60 \pm 4$ & $33.95-111$ & $22 / 23$ & $138 \pm 14$ & $39.2-349$ & None \\
\hline Strontium & $31 / 31$ & $35 \pm 1$ & $25.3-44$ & $45 / 45$ & $44 \pm 1$ & $25.3-71.3$ & $49^{\mathrm{b}}$ \\
\hline Vanadium & $31 / 31$ & $25 \pm 2$ & $12.2-51$ & $45 / 45$ & $28 \pm 2$ & $11.2-61$ & $50^{\mathrm{b}}$ \\
\hline Zinc* & $31 / 31$ & $55 \pm 3$ & $26.6-85$ & $45 / 45$ & $82 \pm 3$ & 37.8-135 & $38^{\mathrm{b}}, 121^{\mathrm{d}}, 123^{\mathrm{c}}, 459^{\mathrm{e}}$ \\
\hline
\end{tabular}

Bold $=$ exceedence of a sediment quality guideline (CCME 2002)

$N D$ number of samples above detection, $N A$ number analyzed, S.E. standard error

${ }^{a}$ Background (Shacklette et al. 1984)

${ }^{\mathrm{b}}$ Background (Buchman 2008)

${ }^{\mathrm{c}}$ Canadian sediment quality guideline (CCME 2002)

${ }^{\mathrm{d}}$ Threshold effects concentration below which adverse effects are not expected to occur (MacDonald et al. 2000)

${ }^{\text {e }}$ Probable Effect Concentration above which adverse effects are expected to occur more often than not (MacDonald et al. 2000)

${ }^{\mathrm{f}}$ Recommended soil criteria (Eisler 1989)

${ }^{g}$ Toxicity threshold for adverse effects to some wildlife species (USDOI 1998)

*Significantly $(p$-value $<0.05$ ) greater on non-buffered than buffered sites as determined by PROC GLIMMIX (SAS Institute 2012) 
Table 6 Summary statistics for water quality measurements at buffered and non-buffered sites from twelve Waterfowl Production Areas, Rainwater Basin, Nebraska, 2007-2009

\begin{tabular}{|c|c|c|c|c|c|c|c|c|c|c|c|c|c|}
\hline Year & Site Category & $\mathrm{N}$ & Mean \pm S.E. & Range & $\mathrm{N}$ & Mean \pm S.E. & Range & $\mathrm{N}$ & Mean \pm S.E. & Range & $\mathrm{N}$ & Mean \pm S.E. & Range \\
\hline & & \multicolumn{3}{|c|}{ Temperature } & \multicolumn{3}{|c|}{ Dissolved Oxygen } & \multicolumn{3}{|c|}{ Specific Conductivity* } & \multicolumn{2}{|l|}{$\mathrm{pH}$} & \\
\hline \multirow[t]{2}{*}{2007} & Buffered & 28 & $20.8 \pm 0.9$ & $10.9-30.0$ & 28 & $5.8 \pm 0.6$ & $0.39-12.25$ & NA & & & 28 & $7.7 \pm 0.2$ & $6.5-9.5$ \\
\hline & Non-buffered & 30 & $21.8 \pm 1.2$ & $6.0-32.5$ & 30 & $4.9 \pm 0.42$ & $1.22-9.65$ & 2 & NA & $236-330$ & 30 & $7.5 \pm 0.2$ & $4-8.7$ \\
\hline \multirow[t]{2}{*}{2008} & Buffered & 88 & $21.5 \pm 0.7$ & $7.2-32.2$ & 86 & $6.6 \pm 0.3$ & $0.79-11.88$ & 88 & $183 \pm 14$ & $42-645$ & 88 & $7.4 \pm 0.1$ & $6.08-9.11$ \\
\hline & Non-buffered & 82 & $20.5 \pm 0.8$ & $5.2-33.7$ & 79 & $7.0 \pm 0.34$ & $1.35-17.31$ & 79 & $268 \pm 23$ & 8-1046 & 82 & $7.6 \pm 0.1$ & $6.64-9.31$ \\
\hline \multirow[t]{3}{*}{2009} & Buffered & 70 & $18.7 \pm 0.8$ & $3.1-37.6$ & 70 & $5.3 \pm 0.4$ & $0.11-12.63$ & 69 & $225 \pm 21$ & $26-768$ & 70 & $7.6 \pm 0.1$ & $6.37-9.47$ \\
\hline & Non-buffered & 70 & $20.2 \pm 0.9$ & $1.7-35.9$ & 70 & $6.4 \pm 0.42$ & $0.09-16.02$ & 70 & $325 \pm 28$ & $64-1070$ & 70 & $8.0 \pm 0.1$ & $5.48-9.78$ \\
\hline & & \multicolumn{3}{|c|}{ Chlorophyl a* } & \multicolumn{3}{|c|}{ Total phosphorus } & \multicolumn{3}{|c|}{ Orthophosphorus } & \multicolumn{2}{|c|}{ Total Nitrogen } & \\
\hline \multirow[t]{2}{*}{2007} & Buffered & 20 & $179.98 \pm 26$ & $64-435$ & 18 & $5.5 \pm 0.6$ & $1.7-10.2$ & NA & & & 28 & $6.6 \pm 1.8$ & $0.0-35.0$ \\
\hline & Non-buffered & 24 & $245.96 \pm 22$ & $106-508$ & 20 & $9.4 \pm 2.0$ & $0-33.0$ & NA & & & 29 & $10.4 \pm 2.8$ & $0.0-35.0$ \\
\hline \multirow[t]{2}{*}{2008} & Buffered & 32 & $256.94 \pm 63$ & $2-869$ & 76 & $1.2 \pm 0.1$ & $0.21-4.1$ & 40 & $0.8 \pm 0.1$ & $0.1-1.8$ & 76 & $2.6 \pm 0.2$ & $1.0-8.0$ \\
\hline & Non-buffered & 29 & $280.92 \pm 68$ & $6-877$ & 75 & $2.4 \pm 0.3$ & $0.21-7.4$ & 39 & $1.6 \pm 0.3$ & $0.1-6.4$ & 75 & $4.7 \pm 0.4$ & $0.4-16.2$ \\
\hline \multirow[t]{3}{*}{2009} & Buffered & 25 & $352.83 \pm 127$ & $7-1600$ & 44 & $1.4 \pm 0.2$ & $0.26-8.1$ & 44 & $0.5 \pm 0.1$ & $0.0-2.0$ & 43 & $6.1 \pm 1.1$ & $0.8-35.8$ \\
\hline & Non-buffered & 22 & $967.59 \pm 166$ & $18-1600$ & 46 & $2.1 \pm 0.3$ & $0.2-11.4$ & 45 & $1.0 \pm 0.3$ & $0.0-9.4$ & 45 & $7.2 \pm 0.8$ & $0.3-23.0$ \\
\hline & & \multicolumn{3}{|c|}{ Chloride } & \multicolumn{3}{|c|}{ Turbidity* } & \multicolumn{3}{|c|}{ Atrazine* } & \multicolumn{3}{|c|}{ Glyphosate } \\
\hline \multirow[t]{2}{*}{2007} & Buffered & NA & & & 28 & $86 \pm 23$ & $10-574$ & NA & & & NA & & \\
\hline & Non-buffered & NA & & & 30 & $596 \pm 81$ & $40-1100$ & NA & & & NA & & \\
\hline \multirow[t]{2}{*}{2008} & Buffered & 40 & $10 \pm 2$ & $1-56$ & 87 & $314 \pm 135$ & $0-9885$ & 41 & $1.2 \pm 0.1$ & $0.08-4.2$ & 20 & $3.1 \pm 0.6$ & $0.06-7.9$ \\
\hline & Non-buffered & 39 & $14 \pm 1$ & $3-39$ & 82 & $617 \pm 105$ & $0-7659$ & 37 & $15.7 \pm 8.6$ & $0.16-287$ & 22 & $3.1 \pm 0.7$ & $0.08-15.2$ \\
\hline \multirow[t]{2}{*}{2009} & Buffered & 43 & $14 \pm 2$ & $1-65$ & 70 & $1020 \pm 305$ & $0-11930$ & 44 & $0.8 \pm 0.1$ & $0.09-4.52$ & 29 & $0.1 \pm 0.0$ & $0.01-0.1445$ \\
\hline & Non-buffered & 46 & $14 \pm 1$ & $3-38$ & 70 & $1182 \pm 347$ & $3.5-20180$ & 46 & $5.8 \pm 3.1$ & $0.29-143.7$ & 34 & $0.4 \pm 0.1$ & $0.08-2.7603$ \\
\hline
\end{tabular}

$N$ sample size, $N A$ not applicable

*Significantly ( $p$-value $<0.05$ ) greater on non-buffered than buffered sites as determined by PROC GLIMMIX (SAS Institute 2012)

were also detected at higher concentrations on non-buffered than buffered sites (Service unpublished data 2009). The mean cadmium concentration in aquatic invertebrates from nonbuffered sites was $0.75 \pm 0.54 \mathrm{mg}$ per kilogram $(\mathrm{mg} / \mathrm{kg}) \mathrm{dw}$ $(n=16)$ and was significantly greater than from invertebrates collected at non-buffered sites $(0.36 \pm 0.28 \mathrm{mg} / \mathrm{kg} \mathrm{dw}, n=13)$. However, the highest concentration of cadmium in aquatic invertebrates $(0.46 \mathrm{mg} / \mathrm{kg} \mathrm{ww}$, from Gleason) did not exceed a $0.54 \mathrm{mg} / \mathrm{kg}$ ww concentration associated with growth reduction in freshwater amphipods (Stanley et al. 2005). Cadmium is known to bioaccumulate in aquatic biota (Eisler 1985) and the higher concentration of cadmium in aquatic invertebrates from non-buffered sites indicates its bioavailability. Although cadmium did not exceed tissue concentrations associated with decreased growth or mortality of freshwater amphipods in the laboratory (Borgmann et al. 1991; Stanley et al. 2005), there is still much uncertainty (e.g. species sensitivities, field conditions) surrounding what tissue concentrations of cadmium should be considered harmful. Cattle manure can be a source of cadmium for plants and invertebrates (Putwattana et al. 2010; EPA 2001) and may be an important source of cadmium in the Rainwater Basin playa wetlands.

Many of the other elemental contaminants detected at higher concentrations at non-buffered sites than buffered sites are the same as those in livestock manure that are of environmental concern including arsenic, copper, selenium, zinc, cadmium, molybdenum, nickel, lead, iron, manganese, aluminum and boron (EPA 2001). Arsenic, copper, selenium and zinc are often included in animal feeds to promote growth or as biocides (Sims 1995). Davis and Bidwell (2008) found that benthic invertebrate richness and diversity may be enhanced in Rainwater Basins wetlands managed with cattle grazing. However, land application of manure or CAFO lagoon effluent as fertilizers on cropland, even at recommended application rates, can result in substantial movement of elemental contaminants along with nitrogen and phosphorous into adjacent wetlands through runoff (Burkholder et al. 2007). CAFO's generate high volumes of phosphorus, nitrogen, potassium and sodium and their presence in the watershed of some of our sites (Cottonwood, Sinninger, Harvard and Linder) was likely associated with increased concentrations of these elements in sediments.

In addition to the effects of nutrient inputs to wetlands, pesticides from surrounding lands can cause direct mortality of invertebrates (Grue et al. 1986). On non-buffered sites, atrazine concentrations observed in the current study exceeded concentrations known to adversely affect aquatic invertebrates. The annual mean concentration of atrazine was significantly 
greater on non-buffered sites for both years and exceeded Nebraska's chronic aquatic life water quality standard of $12 \mu \mathrm{g} / \mathrm{L}$ (NDEQ 2009) at four non-buffered sites (Gleason, Linder, Cottonwood and Hultine). The greatest atrazine concentrations detected in this study were in May of 2008 and included $287 \mu \mathrm{g} / \mathrm{L}$ at Gleason and $162 \mu \mathrm{g} / \mathrm{L}$ at Linder. For comparison, the highest atrazine concentration on a buffered site was $4.5 \mu \mathrm{g} / \mathrm{L}$ at Prairie Dog. Concentrations of atrazine as low as $0.5 \mu \mathrm{g} / \mathrm{L}$ shifted water flea (Daphnia pulicaria) sex ratios towards males and the abundance of emerging chironomids (Labrundinia pilosella) was significantly reduced when exposed to $20 \mu \mathrm{g} / \mathrm{L}$ atrazine (Dewey 1986). In addition to direct effects, atrazine can cause synergistic effects on the toxicity of insecticides to non-target aquatic invertebrates (Jin-Clark et al. 2002; Anderson and Zhu 2004).

Unlike atrazine, glyphosate is used by Rainwater Basin WMD staff to control noxious weeds and this may account for some of the similarity in glyphosate concentrations between buffered and non-buffered sites in 2008 and the rather high concentrations (above $3 \mu \mathrm{g} / \mathrm{L}$ ) detected at three buffered sites (Real, Massie and Moger). The highest observed concentrations of glyphosate in wetland water were 15.2 and $8.7 \mu \mathrm{g} / \mathrm{L}$ at Harvard WPA, a site where direct runoff from glyphosate-treated soybean fields was expected to occur. There are no water quality standards for glyphosate, but no sites had concentrations above an interim Canadian guideline of $65 \mu \mathrm{g} / \mathrm{L}$ (CCME 1999).

During the time of sampling, atrazine and glyphosate were likely the most frequently applied herbicides in Nebraska for corn and soybeans, respectively (NASS 2010). The increased presence of pesticides on non-buffered sites, along with the increases in nutrients, salts and select elemental contaminants clearly suggest that runoff from agriculture is contributing to water quality degradation of non-buffered WPA sites. Contaminated sediments and water associated with non-buffered sites coupled with the decreases in aquatic invertebrate diversity and abundance at the same sites may indicate overall habitat degradation for waterfowl and possibly other organisms such as amphibians (Papoulias et al. 2012).

Riparian buffer zones (vegetated filter strips) are permanently vegetated areas that serve as a buffer between pollutant sources and water bodies (Narumalani et al. 1997). This vegetative cover increases hydraulic roughness while decreasing surface flow velocities which limit sediment and nutrient influxes (USDA 1991). Riparian buffer zones have been shown to limit pollution input to water sources (Muscutt et al. 1993; Osborne and Kovacic 1993) with various buffer strip sizes being implemented. This study did not directly test the effects of buffer strip widths on water quality or macroinvertebrate diversity and no trends were noticed during sampling. In addition, the buffer size needed to significantly improve water quality and macroinvertebrate diversity may depend on characteristics of the wetland's watershed such as drainage slope and size rather than being a fixed size. A 24-m grass buffer around an English waterway dramatically reduced pollutants in the water (Haycock and Burt 1991). Similar buffer widths reduced concentrations of nitrogen and phosphorus entering water bodies as surface runoff from agricultural fields (Peterjohn and Correll 1984). It appears that the presence of modest vegetative buffers will improve water quality by reducing contamination and thus, assist in protecting wetland invertebrate communities.

This study showed invertebrate numbers and diversity differed between buffered and non-buffered sites. Water quality parameters and contaminant variables appear to have an influence on resident macroinvertebrate communities. Arguably the most alarming result of this study is the lack of representation of many key families of macroinvertebrates in non-buffered sites (Table 1). When these macroinvertebrates disappear, a breakdown of community composition and therefore biological services can occur (Williams 2006). Biological services including nutrient cycling are critical to preventing elements such as nitrogen and phosphorus from accumulating in the wetland, further degrading the habitat (Davis and Bidwell 2008). Future research is needed to better understand the effects of vegetative buffers on ecosystem services. In addition, changes in water quality parameters during peak runoff periods should be examined.

Acknowledgments Funding for this research was provided by the U.S. Fish and Wildlife Service, On-Refuge Environmental Contaminants fund and the University of Nebraska at Kearney Research Services Council. The findings and conclusions in this article are those of the authors and do not necessarily represent the views of the U.S. Fish and Wildlife Service. The authors would like to thank the following for their assistance with this research: Joseph DeCant, Lourdes Mena, LaNae Hays, Jeff Drahota, Nadeeshani Jayasena, David Marx, Kerri Farnsworth-Hoback, Keith Koupal, Roger Grosse, Drew Prososki, Kathy Maline, Jason Gfeller, and Nancy Riens. Thanks to Ward Laboratories for discounted analytical services.

\section{References}

Adamus PR (1996) Bioindicators for assessing ecological integrity of prairie wetlands. U.S. Environmental Protection Agency, Corvalis

Anderson TD, Zhu KY (2004) Synergistic and antagonistic effects of atrazine on the toxicity of organophosphorodithioate and organophosphorothioate insecticides to Chironomus tentans (Diptera: Chironomidae). Pesticide Biochemistry and Physiology 80:54-64

Batzer DP, Rader RB, Wissinger SA (1999) Invertebrates in freshwater wetlands of North America: ecology and management. John Wiley and Sons, Incorporated, New York

Belden JB, Hanson BR, McMurry ST, Smith LM, Haukos DA (2012) Assessment of the effects of farming and conservation programs on pesticide deposition in high plains wetlands. Environmental Science and Technology 46:3424-3432 
Bishop A, Walters R, Drahota J (2004) Rainwater Basin wetland complex vegetation mapping and monitoring project, final report. Rainwater Basin Joint Venture, U.S. Fish and Wildlife Service, Nebraska Game and Parks Commission and U.S. Fish and Wildlife Service, Nebraska Game and Parks Commission and U.S. Bureau of Reclamation, Grand Island

Borgmann U, Norwood WP, Babirad IM (1991) Relationship between chronic toxicity and bioaccumulation of cadmium in Hyalella azteca. Canadian Journal of Fisheries and Aquatic Sciences 48:1055-1060

Buchman MF (2008) Screening quick reference tables, NOAA OR\&R report 08-1. Office of Response and Restoration Division, National Oceanic and Atmospheric Administration. Seattle, WA. http://response.restoration.noaa.gov/book_shelf/12. Accessed 15 Mar 2010

Burkholder J, Libra B, Weyer P (2007) Impacts on waste from concentrated animal feeding operations on water quality. Environmental Health Perspectives 115(2):308-312

Canadian Council of Ministries of the Environment (CCME) (1999) Canadian water quality guidelines for the protection of aquatic life: glyphosate. In: Canadian Council of Ministries of the Environment, Canadian Environmental Quality Guidelines, 1999. A Canadian Council of Ministries of the Environment Report. Winnipeg, Manitoba

Canadian Council of Ministries of the Environment (CCME) (2002) Canadian sediment quality guidelines for the protection of aquatic life: Summary tables. Updated. In: Canadian environmental quality guidelines, 1999. Canadian Council of Ministers of the Environment, Winnipeg

Davis CA, Bidwell JR (2008) Response of aquatic invertebrates to vegetation management and agriculture. Wetlands 28(3):793-805

Dewey SL (1986) Effects of the herbicide atrazine on aquatic insect community structure and emergence. Ecology 67:148-162

Douglas GM (2001) Pennak's freshwater invertebrates of the United States: prorifera to crustacean. John Wiley and Sons Publishing Company, Hoboken

Eisler R (1985) Cadmium hazards to fish, wildlife, and invertebrates: a synoptic review. U.S. Fish and Wildlife Service Biological Report 85(1.20) Report \#2. 30 pp. http://www.pwrc.usgs.gov/infobase/ eisler/reviews.cfm. Accessed 2 Apr 2010

Eisler R (1989) Molybdenum hazards to fish, wildlife, and invertebrates: a synoptic review. U.S. Fish and Wildlife Service Biological Report 85(1.19) Report \#19. 43 pp. http://www.pwrc.usgs.gov/infobase/ eisler/reviews.cfm. Accessed 15 Mar 2010

Euliss NH, Mushet DM (1999) Influence of agriculture on aquatic invertebrate communities of temporary wetlands in the Prairie Pothole Region of North Dakota, USA. Wetlands 19:578-583

Gordon CC, Flake LD, Higgins KF (1990) Aquatic invertebrates in the rainwater basin area of Nebraska. The Prairie Naturalist 23(3):191200

Gordon CC, Flake LD, Higgins KF (1997) Trace metals in water and sediments of wetlands in the Rainwater Basin area of Nebraska. Proceedings of the South Dakota Academy of Sciences 72:253261

Grue CE, DeWeese LR, Mineau P, Swanson GA, Foster JR, Arnold PM, Huckins JN, Sheehan PJ, Marshall WK, Ludden AP (1986) Potential impacts of agricultural chemicals on waterfowl and other wildlife inhabiting prairie wetlands: an evaluation of research needs and approaches. Transactions of the North American Wildlife and Natural Resources Conference 51:357-383

Haycock NE, Burt TP (1991) The sensitivity of rivers to nitrate leaching: the effectiveness of near-stream land as a nutrient retention zone. In: Allison RJ, Thomas DS (eds) Landscape Sensitivity. Wiley, London, pp 312-319

Hayes TB, Khoury V, Narayana A, Nazir M, Park A, Brown T, Adame L, Chan E, Buchholz D, Stueve T, Gallipeau S (2010) Atrazine induces complete feminization and chemical castration in male
African clawed frogs (Xenopus laevis). Proceedings of the National Academy of Sciences 107:4612-4617

Hemesath LM (1991) Species richness and nest productivity of marsh birds on restored prairie potholes in norther Iowa. M.S. Thesis, Iowa State University, Ames, IA

Hentges VA, Stewart TW (2010) Macroinvertebrate assemblages in Iowa Prairie pothole wetlands and relation to environmental features. Wetlands 30:501-511

Jin-Clark Y, Lydy MJ, Zhu KY (2002) Effects of atrazine and cyanazine on chloropyrifos toxicity in Chironomus tentans (Diptera: Chironomidae). Environmental Toxicology and Chemistry 21(3):598-603

LaGrange T (2005) Guide to Nebraska's Wetlands and their conservation needs. Nebraska Game and Parks Commission. Lincoln, Nebraska. http://outdoornebraska.ne.gov/conservation.asp. Accessed 13 Aug 2009

Levy S (1998) Using bugs to bust polluters. BioScience 48(5):342-346

MacDonald DD, Ingersoll CG, Berger TA (2000) Development and evaluation of consensus-based sediment quality guidelines for freshwater ecosystems. Archives of Environmental Contamination and Toxicology 39:20-31

Mackie G (2004) Applied aquatic ecosystem concepts. Kendal/Hunt Publishing Company, Dubuque

Merritt RW, Cummins KW, Berg MB (2008) An introduction to the aquatic insects of North America. Kendall/Hunt Publishing Company, Dubuque

Mitsch WJ, Gosselink JG (2000) Wetlands, 3rd edn. John Wiley and Sons, Incorporated, New York

Muscutt AD, Harris GL, Bailey SW, Davies DB (1993) Buffer zones to improve water quality: a review of their potential use in UK agriculture. Agricultural Ecosystem Environment 45:59-77

Narumalani S, Zhou Y, Jensen JR (1997) Application of remote sensing and geographic information systems to the delineation and analysis of riparian buffer zones. Aquatic Botany 58:393409

National Agricultural Statistics Service (NASS) (2010) Agricultural chemical usage reports. http://www.nass.usda.gov/statistics_by subject/environmental/index.asp. Accessed 20 Jun 2011

Nebraska Department of Environmental Quality (NDEQ) (2009) Title 117 Nebraska water quality standards. http://www.deq.state.ne.us/. Accessed 3 Jan 2011

Nelson SM, Roline RA, Thullen JS, Sartoris JJ, Boutwell JE (2000) Invertebrate assemblages and trace element bioaccumulation associated with constructed wetlands. Wetlands 20(2):406-415

Osborne LL, Kovacic DA (1993) Riparian vegetated buffer strips in water quality restoration and stream management. Freshwater Biology 29(2):243-258

Papoulias MS, Schwarz M, Lourdes M (2012) Gonadal abnormalities in frogs (Lithobates spp.) collected from managed wetlands in an agricultural region of Nebraska, USA. Environmental Pollution $172: 1-8$

Pederson RL, Jorde DG, Simpson SG (1989) Northern great plains. In: Smith LM, Pederson RL, Kaminski RM (eds) Habitat management for migrating and wintering waterfowl in North America. Texas Tech University Press, Lubbock, pp 281-310

Peterjohn WT, Correll DL (1984) Nutrient dynamics in an agricultural watershed: observations on the role of a riparian forest. Ecology 65:1466-1475

Putwattana N, Kruatrachue M, Pokethitiyook P, Chaiyarat R (2010) Immobilization of cadmium in soil by cow manure and silicate fertilizer, and reduced accumulation of cadmium in sweet basil (Ocimum basilicum). ScienceAsia 36:349-354

Resh VH, Meyers MJ, Hannaford MJ (1996) Macroinvertebrates as biotic indicators of environmental quality. In: Hauer FR, Lamberti GA (eds) Methods in stream ecology. Academic, San Diego, pp 647-667

SAS Institute (2012) Version 9.3. SAS Institute, Cary 
Schildman G, Hurt J (1984) Update of the rainwater basin wetland survey. Survey of the habitat work plan K-83, Pittman-Robertson Project W15-R-40. Nebraska Game and Parks Commission, Lincoln

Schulz R (2004) Field studies on exposure, effects, and risk mitigation of aquatic non-source insecticide pollution: a review. Journal of Environmental Quality 33:419-448

Schwarz MS, Echols KR, Wolcott MJ, Nelson KJ (2004) Environmental contaminants associated with swine concentrated animal feeding operation and implications for McMurtrey National Wildlife Refuge. US Fish and Wildlife Service Contaminant Report, Grand Island

Sewell RW, Higgins KF (1991) Floral and faunal colonization of restored wetlands in west-central Minnesota and northeastern South Dakota. Proceeding of the 18th annual conference on wetland restoration and creation. Hillsborough College, Tamapa

Shacklette HT, Boerngen JG (1984) Element concentrations in soils and other surficial materials of the conterminous United States. Professional paper 1270. U.S. Geological Survey, Washington D.C.

Sims TJ (1995) Characteristics of animal wastes and waste-amended soils: an overview of the agricultural and environmental issues. In: Steel K (ed) Animal Waste and the Land-water Interface. Lewis Publishers, Boca Raton

Smith LM (1998) Research needs for the rainwater basin of $\mathrm{Ne}-$ braska: a hierarchical approach. Rainwater Basin Joint Venture, Grand Island. http://www.rwbjv.org. Accessed 27 Nov 2009

Spieles DJ, Mitsch WJ (2000) Macroinvertebrate community structure in high- and low-nutrient constructed wetlands. Wetlands 20(4): 716-729

Stanley JK, Brooks BW, La Point TW (2005) A comparison of chronic cadmium effects on Hyalella Azteca in effluent-dominated stream mesocosms to similar laboratory exposures in effluent and reconstituted hard water. Environmental Toxicology and Chemistry 24(4):902-908

Steinman AD, Conklin J, Bohlen PJ (2003) Influence of cattle grazing and pasture land use on macroinvertebrate communities in freshwater wetlands. Wetlands 23(4):877-889
Turner AM, Trexler JC (1997) Sampling aquatic invertebrates from marshes: evaluating the options. Journal of the North American Benthological Society 16(3):694-709

U.S. Department of Agriculture (USDA) (1991) Riparian forest buffers: function and design for protection and enhancement of water resources. USDA Forest Service, Forest Resources Management, Radnor

U.S. Department of the Interior (USDOI) (1998) Guidelines for the interpretation of the biological effects of selected constituents in biota, water, and sediment. National Irrigation Water Quality Program Information Report No.3. U.S. Department of the Interior, Denver

U.S. Environmental Protection Agency (EPA) (2001) Environmental assessment of proposed revisions to the national pollutant discharge elimination system regulation and the effluent guidelines for concentrated animal feeding operations, EPA-821-B-01-001. http://www.epa.gov/ost/guide/cafo/envir.html. Accessed 15 Mar 2010

U.S. Fish and Wildlife Service (Service) (2007) Comprehensive conservation plan. Rainwater Basin Wetland Management District. Kearney http://www.fws.gov/mountain-prairie/planning/ccp/ne/rwb. html. Accessed 27 Nov 2009

U.S. Fish and Wildlife Service (Service) (2009) An evaluation of agricultural chemical exposure and effects to wildlife on Waterfowl Production Areas in the Rainwater Basin Wetland Management District. U.S. Fish and Wildlife Service Raw Data, Grand Island

Van Dam RA, Camilleri C, Finlayson CM (1998) The potential of rapid assessment techniques as early warning indicators of wetland. Environmental Toxicology and Water Quality 13(4):297-312

Voshell JR (2005) A guide to common freshwater invertebrates of North America. Mcdonald and Woodward Publishing Company, Blacksburg

Williams DD (1996) Environmental constraints in temporary fresh waters, and their consequences for insect fauna. Journal of the North American Benthological Society 15:634-650

Williams DD (2006) The biology of temporary waters. Oxford University Press, New York 